UDC 342.9

Prokhorov Kostiantyn,

Postgraduate of the Interregional

Academy of Personnel Management,

Kyiv, Ukraine

\title{
THE DECLARATION OF PERSONS AUTHORIZED TO IMPLEMENT THE FUNCTIONS OF THE STATE OR LOCAL SELF-GOVERNMENT AS ONE OF THE MEANS OF PREVENTION OF CORRUPTION
}

The purpose of paper was to identify the properties of the declaration of persons authorized to perform functions of the state or local government as one of means of preventing corruption.

The author found out that the implementation of the declaration of persons authorized to perform the functions of the state or local self-government allowed to make qualitative changes in the system of preventing corruption in Ukraine. At the same time, the paper states that the social significance of submitting and publishing these declarations has not been investigated yet.

It is substantiated that the development of information technologies makes it possible to use new, previously unknown, means of preventing corruption, the use of which can significantly improve the effectiveness of achieving a proper state of integrity in the state. Such measures include the keeping of the Unified State Register of Declarations of Persons Authorized to Perform the Functions of State or Local SelfGovernment. The author concludes that the value of submitting and publishing the specified type of declarations can simultaneously achieve three goals: to increase the level of transparency and openness in certain areas of public administration; to create positive and negative models of behavior of officials, observance of each of which entails certain legal consequences; involve the general public and the media in the exercise of democratic civilian control over the functioning of the public administration system. 
Paper found that the filing of declarations by persons authorized to perform state or local government functions is one of the means of preventing corruption due to the influence of the following factors. First, by filing and promulgating the aforementioned declarations, the public and the state are able to respond promptly to the facts of officials' misconduct, both related to the concealment of certain information and to the conflict of interests or inconsistency of the declared and actual statuses. Secondly, declaration as a social phenomenon is one of the manifestations of the government's accountability to citizens, which is a feature of a democratic society. Third, the filing of declarations makes it possible to exercise the so-called promising legal liability, the essence of which is the honest observance of the requirements of public officials by serving as a positive model of the behavior of a person authorized to perform the functions of the state or local authorities.

Keywords: corruption, prevention of corruption, declarations of persons authorized to perform the functions of the state or local government; means of preventing corruption, positive legal liability, public service.

\section{REFERENCES}

1. CPI-2018: Ukraina znovu hirshe vsikh susidiv, okrim Rosii. TI Ukraina. "Ukraine is again worse than all its neighbors, except Russia". TI Ukraine" (date of application: 10.10.2019) [in Ukrainian].

2. Pro ratyfikatsiiu Konventsii Orhanizatsii Obiednanykh Natsii proty koruptsii. "On the Ratification of the United Nations Convention Against Corruption". Information of the Verkhovna Rada of Ukraine. 2006. No 50. Art. 496 [in Ukrainian].

3. Lytvynov O.M., Hladkova Ye. (2018) Suchasnyi stan i perspektyvy protydii koruptsii v Ukraini. "A Current Status and Prospects of Combating Corruption in Ukraine". Implementation of State Anti-Corruption Policy in the International Dimension: Materials of the III International Scient.-Pract. Conf. : in 2 books (Kyiv, Dec. 7, 2018). Kyiv: NASA. Part 1. P. 104-107 [in Ukrainian].

4. On Military Duty and Military Service: Law of Ukraine dated March 25, 1992 N. 2232-XII. URL: https://zakon.rada.gov.ua/laws/show/2232-12 (date of application: 10.10.2019) [in Ukrainian]. 
5. On Prevention of Corruption: Law of Ukraine dated October 14, 2014. No 1700-VII. URL: https://zakon.rada.gov.ua/laws/main/1700-18 (date of application : 10.10.2019) [in Ukrainian].

6. Shopina I., Tarasov S. (2019) Koruptsiini ryzyky yak faktor znyzhennia boiezdatnosti viiskovykh chastyn. "Corruption Risks as a Factor in Reducing the Combat Capability of Military Units". State and Prospects for Reforming the Security and Defense Sector of Ukraine: Proceedings of the International Scientific and Practical Conference (November 24, 2017): in 2 Vol. K.: National Academy of Public Prosecutor of Ukraine, 2017. Vol. 1. P. 463-465 [in Ukrainian].

7. Viiskove pravo. "Martial Law": textbook / eds. I. Koropatnik, I. Shopina. Kyiv: Alerta, 2019. 648 p. [in Ukrainian].

8. Informatsiina kultura v Ukraini: pravovyi vymir." Information Culture in Ukraine: Legal Aspects": monograph / ed. K.I. Beliakov. Kyiv: KVIC, 2018. 169 p. [in Ukrainian]. 